\title{
Upaya Meningkatkan Disiplin Guru Dalam Kehadiran Mengajar Di Kelas Melalui Penerapan Reward And Punishment Di SDI Wolowona 1 Kabupaten Ende
}

\author{
Elias Rhando
}

Kepala Sekolah Dasar Inpres Wolowona 1, Ende, NTT

\begin{abstract}
ABSTRAK: Peningkatan mutu pembelajaran di sekolah sangat tergantung dari beberapa faktor. Faktor yang sangat penting antara lain adalah penerapan budaya sekolah kearah peningkatan mutu. Budaya sekolah merupakan hal yang positif yang harus dipertahankan dan dilaksanakan oleh semua warga sekolah tanpa merasa terpaksa. Budaya sekolah yang harus dipertahankan salah satunya adalah masalah kedisiplinan, termasuk disiplin para guru dalam kehadiran di kelas pada proses belajar mengajar. Dalam Penelitian Tindakan Sekolah (PTS) ini, dicobakan tindakan berupa penerapan Reward and Punishment untuk para guru di SDI Wolowona 1, Kabupaten Ende. Penelitian ini dilaksanakan dalam dua siklus, karena dari hasil penelitian dan analisa data, ternyata pada siklus kedua, kedisiplinan guru dalam kehadiran dikelas pada proses belajar mengajar meningkat dan memenuhi indikator yang telah ditetapkan sebesar 75\%. Dari hasil penelitian ini, dapat disimpulkan bahwa untuk meningkatkan disiplin guru dalam kehadiran di kelas pada kegiatan belajar mengajar dapat dilakukan dengan penerapan Reward and Punishment kepada guru.
\end{abstract}

Kata kunci : disiplin guru, reward and punishment.

ABSTRACT: Improving the quality of learning in schools is very dependent on several factors. Very important factors include the application of school culture towards improving quality. School culture is a positive thing that must be maintained and implemented by all school residents without feeling compelled. One of the culture of schools that must be maintained is the problem of discipline, including the discipline of the teachers in attending class in the teaching and learning process. In this School Action Research (PTS), an attempt was made in the form of implementing Reward and Punishment for teachers at SDI Wolowona 1, Ende Regency. This research was conducted in two cycles, because from the results of research and data analysis, it turns out that in the second cycle, teacher discipline in class attendance at the teaching and learning process increased and met the indicators set by $75 \%$. From the results of this study, it can be concluded that to improve teacher discipline in class attendance at teaching and learning activities can be done by applying Reward and Punishment to teachers.

Keywords: reward and punishment, teacher discipline.

\section{PENDAHULUAN}

Guru adalah pendidik profesional dengan tugas utama mendidik, mengajar, membimbing, mengarahkan, melatih, menilai, dan mengevaluasi peserta didik pada pendidikan anak usia dini jalur pendidikan formal, pendidikan dasar,dan pendidikan menengah. (UU No. 14, Tahun 2005) Guru sebagai tenaga profesional mengandung arti bahwa pekerjaan guru hanya dapat dilakukan oleh seseorang yang mempunyai kualifikasi akademik, kompetensi, dan sertifikat pendidik sesuai dengan persyaratan untuk setiap jenis dan jenjang pendidikan tertentu. .Untuk mencapai tujuan pembelajaran di sekolah perlu kedisiplinan guru dan pegawai dalam mematuhi semua aturan dan norma yang 
ada dalam menjalankan tugasnya sebagai bentuk tanggung jawabnya terhadap pendidikan anak didiknya.

Keteladanan guru dapat dilihat dari prilaku guru sehari-hari baik di dalam sekolah maupun diluar sekolah. Selain keteladanan guru, kedisiplinan guru juga menjadi salah satu hal penting yang harus dimiliki oleh guru sebagai seorang pengajar dan pendidik. Fakta di lapangan yang peneliti jumpai di SDI Wolowona 1 adalah kurang disiplinnya guru, terutama masalah disiplin guru masuk ke dalam kelas pada saat kegiatan pembelajaran di kelas.

\section{LANDASAN TEORI}

Di masa lalu, kepala sekolah yang berperan sebagai manajer yang efektif telah dianggap cukup. Akan tetapi, sekarang kepala sekolah harus melakukan hal yang lebih dari semua itu. Berbagai penelitian menunjukkan peran kunci yang dapat dilakukan kepala sekolah agar dapat meningkatkan belajar dan pembelajaran, kepala sekolah harus berperan sebagai leaders for learning (The Institute for Educational Leadership, 2000). Para kepala sekolah harus mengetahui isi pelajaran dan teknik-teknik pedagogis. Selanjutnya para kepala sekolah itu juga harus memiliki keterampilan dan pengetahuan kepemimpinan dalam rangka memanfaatkan kewenangannya untuk mencari strategi-strategi yang diperlukan. Masyarakat pada umumnya memberi sorotan kepada kepala sekolah ketika hasil Ujian Nasional siswa diumumkan dan mengajukan usul untuk memberi sanksi apabila sekolah tidak menunjukkan hasil sebagaimana diharapkan.

Pendidikan bukan hanya menyampaikan keterampilan yang sudah dikenal, namun harus dapat meramalkan berbagai jenis keterampilan dan kemahiran yang akan datang, dan sekaligus menemukan cara yang tepat dan cepat dikuasai oleh anak didik.(Budiningsih,2005). $\quad$ Fungsi pendidikan dapat meningkatkan kesejahteraan, karena seseorang yang berpendidikan atau memiliki pendidikan tersebut dapat terhindar dari kebodohan dan juga kemiskinan. Kedudukan guru dipahami demikian penting sebagai ujung tombak dalam pembelajaran dan pencapaian mutu hasil belajar peserta didik (Sagala, 2003). Kinerja guru menjadi salah satu unsur dalam upaya peningkatan mutu sekolah. Apabila kedisiplinan telah menjadi budaya sekolah, maka arah pencapaian peningkatan mutu sekolah akan tercapai.

Penerapan disiplin warga sekolah, khususnya disiplin guru dalam melaksanakan proses belajar mengajar sangat berkait kepada kinerja guru itu sendiri. Heidjrachman dan Husnan, (2002: 15) mengungkapkan "Disiplin adalah setiap perseorangan dan juga kelompok yang menjamin adanya kepatuhan terhadap perintah" dan berinisiatif untuk melakukan suatu tindakan yang diperlukan seandainya tidak ada perintah". Sedangkan De Cenzo dan Robbins (1994:451) mengemukakan tipe permasalahan dalam kedisiplinan, antara lain : kehadiran, perilaku dalam bekerja (dalam lingkungan kerja), ketidak jujuran, aktivitas di luar lingkungan kerja.

Selama ini yang terjadi di SDI Wolowona 1 adalah seringnya kelas kosong saat jam belajar. Bagi guru, ketidakhadiran dalam mengajar sesuai jadwal terkadang merupakan suatu hal yang tidak terhindarkan keterlambatan mengajar di kelas selalu dan sering terjadi. Hal ini berdampak buruk terhadap proses pembelajaran. Pertama, siswa menjadi kecewa, dan hal ini dapat menurunkan motivasi belajar mereka. Siswa memperoleh contoh yang buruk tentang kedisiplinan. Kedua, guru yang mengajar dengan sungguh-sungguh merasa usahanya menjadi sia-sia dan sekaligus kecewa. Apa yang mereka bangun dipatahkan oleh rekan seprofesinya. Belum lagi, apabila guru yang disiplin dalam mengajar, memperoleh pendapatan yang sama dengan guru yang jarang mengajar di kelas. Dampak dari guru yang tidak 
disiplin dalam mengajar bukan semata ditanggung mereka namun juga seluruh institusi atau warga sekolah. Perilaku tidak disiplin dalam mengajar juga bisa menjadi virus bagi guru yang biasanya rajin mengajar.

Penerapan disiplin dapat ditegakan melalui pemberian reward and punishment. Reward dan punishment merupakan dua bentuk metode dalam memotivasi seseorang untuk melakukan kebaikan dan meningkatkan prestasinya. Kedua metode ini sudah cukup lama dikenal dalam dunia kerja. Dalam dunia penidikan pun kedua metode ini kerap kali digunakan. Reward artinya ganjaran, hadiah, penghargaan atau imbalan. Dalam konsep manajemen, reward merupakan salah satu alat untuk peningkatan motivasi para pegawai. Sementara punishment diartikan sebagai hukuman atau sanksi. Jika reward merupakan bentuk reinforcement yang positif; maka punishment sebagai bentuk reinforcement yang negatif, tetapi kalau diberikan secara tepat dan bijak bisa menjadi alat motivasi. Tujuan dari metode ini adalah menimbulkan rasa tidak senang pada seseorang supaya mereka jangan membuat sesuatu yang jahat. Jadi, hukuman yang dilakukan mesti bersifat pedagogies, yaitu untuk memperbaiki dan mendidik ke arah yang lebih baik. Reward yang diberikan pun harus secara adil dan bijak. Jika tidak, reward malah menimbulkan rasa cemburu dan "persaingan yang tidak sehat" serta memicu rasa sombong bagi pegawai yang memperolehnya. Sebaliknya, jika punishment memang harus diberlakukan, maka laksanakanlah dengan cara yang bijak lagi mendidik, tidak boleh sewenangwenang, tidak pula menimbulkan rasa kebencian yang berlebihan sehingga merusak tali silaturrahim.

Peran reward dan punishment bagi SDM inipun juga harus dibawa menjadi bentuk participative. Likert (1967) menyebutkan dalam salah satu sistem manajemen participative ini mengakui dan berusaha memenuhi kebutuhan-kebutuhan manusiawi para pekerja. Tidak saja kebutuhan faali, tetapi juga kebutuhankebutuhan lainnya. Penerapan lain juga bisa diterapkan bagi karyawan atau aparatur meningkatkan disiplin SDM aparatur yang masih rendah dengan perubahan perilaku yang mendasar. Hal itu terjadi melalui revitalisasi pembinaan kepegawaian dan proses pembelajaran dengan membangun komitmen kuat dalam mengemban tugas sebagai pegawai negeri sipil, disertai pengembangan sistem reward dan punishment yang tepat dan efektif (Bambang Nugroho, 2006).

Pemberian rewards and punishments sangat berkaitan dengan terlaksananya kedisiplinan guru dalam kegiatan belajar mengajar di kelas. Kepala sekolah selaku pemimpin pembelajaran mempunyai peran yang sangat strategis dalam pencapaian tujuan sekolah dalam meningkatkan mutu. Salah satu faktor yang penting adalah adanya keteladanan (contoh) dalam kedisiplinan yang diberikan oleh kepala sekolah. Hal ini seperti falsafah pendidikan yang dikemukakan oleh Bapak Pendidikan Nasional Ki Hadjar Dewantara, "Ing Ngarso Sung Tulodho.”Kepala sekolah selaku pemimpin pembelajaran harus bisa memberikan contoh kepada semua wara sekolah agar tercipta budaya disiplin disekolah, yang pada akhirnya akan meningkatkan mutu sekolah.

Dalam upaya penerapan kedisiplinan guru pada kehadiran di kelas dalam kegiatan belajar mengajar, bisa ditempuh dengan beberapa upaya. Adapun upaya dalam meningkatkan disiplin guru adalah sebagai berikut: (a) sekolah memiliki system pengendalian ketertiban yang dikelola dengan baik, (b) adanya keteladanan disiplin dalam sikap dan prilaku dimulai dari pimpinan sekolah, (c) mewajibkan guru untuk mengisi agenda kelas dan mengisi buku absen yang diedarkan oleh petugas piket, (d) pada awal masuk sekolah kepala sekolah bersama guru membuat kesepakatan tentang aturan kedisiplinan, 
memperkecil kesempatan guru untuk ijin meninggalkan kelas, dan (f) setiap rapat pembinaan diumumkan frekuensi pelanggaran terendah. Dengan strategi tersebut diatas kultur disiplin guru dalam kegiatan pembelajaran bisa terpelihara dengan baik, suasana lingkungan belajar aman dan terkendali sehingga siswa bisa mencapai prestasi belajar yang optimal.

\section{PEMBAHASAN}

Metode yang digunakan dalam penelitian ini adalah metode Penelitian Tindakan Sekolah (PTS). PTS merupakan suatu prosedur penelitian yang diadaptasi dari Penelitian Tindakan Kelas (PTK) (Panitia Pelaksana Pendidikan dan Latihan Profesi Guru Rayon 10 Jawa Barat, 2009 : 73). Penelitian tindakan sekolah merupakan "(1) penelitian partisipatoris yang menekankan pada tindakan dan refleksi berdasarkan pertimbangan rasional dan logis untuk melakukan perbaikan terhadap suatu kondisi nyata; (2) memperdalam pemahaman terhadap tindakan yang dilakukan; dan (3) memperbaiki situasi dan kondisi sekolah / pembelajaran secara praktis" (Depdiknas, 2008 : 11-12). Secara singkat, PTS bertujuan untuk mencari pemecahan permasalahan nyata yang terjadi di sekolah-sekolah, sekaligus mencari jawaban ilmiah bagaimana masalahmasalah tersebut bisa dipecahkan melalui suatu tindakan perbaikan.

Pendekatan yang digunakan dalam penelitian tindakan ini ialah pendekatan kualitatif. Artinya, penelitian ini dilakukan karena ditemukan permasalahan rendahnya tingkat kedisiplinan guru dalam kehadiran dikelas pada proses kegiatan belajar mengajar. Permasalahan ini ditindaklanjuti dengan cara menerapkan sebuah model pembinaan kepada guru berupa penerapan Reward dan Punishment yang dilakukan oleh kepala sekolah, kegiatan tersebut diamati kemudian dianalisis dan direfleksi. Hasil revisi kemudian diterapkan kembali pada siklus-siklus berikutnya. Penelitian ini adalah penelitian tindakan model
Stephen Kemmis dan Mc. Taggart (1998) yang diadopsi oleh Suranto $(2000 ; 49)$ yang kemudian diadaptasikan dalam penelitian ini. Model ini menggunakan sistem spiral refleksi diri yang dimulai dari rencana, tindakan, pengamatan, refleksi, dan perencanaan kembali yang merupakan dasar untuk suatu ancang-ancang pemecahan masalah. Seperti yang diungkapkan oleh Mills (200;17)

Penelitian Tindakan Sekolah (PTS) ini dilaksanakan dalam dua siklus. Hal ini dikarenakan keterbatasan waktu yang tersedia, serta dengan dua siklus sudah penulis anggap cukup untuk peningkatan disiplin guru dalam kehadiran di kelas pada kegiatan belajar mengajar.Indikator keberhasilan penerapan tindakan ini penulis tetapkan sebesar 75\%, artinya tindakan ini dinyatakan berhasil bila $75 \%$ guru tidak terlambat masuk kelas dalam proses pembelajaran. Langkah-langkah yang diambil penulis dalam melakukan tindakan antara lain adalah melakukan sosialisasi kepada para guru mengenai penelitian yang akan dilaksanakan, serta menyampaikan tujuan dari penerapan tindakan yang dilakukan oleh penulis. Kepada para guru disampaikan mengenai penerapan Reward dan Punishment yang akan diterapkan dalam penelitian ini. Pada siklus pertama ini, akan dipampang/ditempel diruang guru, maupun diruang TU, peringkat nama-nama guru yang paling rendah tingkat keterlambatan masuk kelasnya sampai yang paling tinggi tingkat keterlambatannya.

Pelaksanaan penelitian tindakan sekolah ini dilaksanakan melalui beberapa kegiatan, antara lain :

(a) Menyebarkan lembar pengamatan kepada setiap Ketua Kelas atau Sekretaris kelas sebanyak 12 set, sesuai dengan banyaknya jumlah rombongan belajar di SDI Wolowona 1 sebanyak 12 rombongan belajar. Dalam lembar pengamatan itu, telah dibuat daftar guru yang mengajar di kelas itu 
setiap jam dan diberi kolom jam masuk kelas serta jam keluar kelas.

(b) Berkoordinasi dengan petugas piket yang setiap hari terdiri dari 2 orang petugas, yaitu dari guru yang tidak mempunyai jam mengajar pada hari itu dan satu orang dari tata usaha. Petugas piket akan mengedarkan daftar hadir guru di kelas yang telah dibuat agar dapat melihat tingkat kehadiran guru disetiap kelas dan disetiap pergantian jam pelajaran. Guru yang terlambat lebih dari 15 menit, dianggap tidak hadir dan diberi tanda silang.

(c) Setelah selesai jam pelajaran, dilakukan rekapitulasi dari hasil pengamatan, baik dari guru piket, dari siswa maupun dari penulis.

(d) Kegiatan tersebut dilakukan terus setiap hari kepada setiap guru selama satu minggu (satu siklus).

\begin{abstract}
Pengamatan atau observasi dilakukan oleh peneliti dengan menggunakan lembar observasi selama satu minggu (satu siklus), untuk semua guru yang berjumlah 18 orang. Dari hasil rekapitulasi tingkat keterlambatan guru di kelas pada proses pembelajaran diperoleh data, sebanyak 5 orang guru terlambat masuk kelas kurang dari 10 menit, 7 orang guru terlambat masuk kelas 10 menit sampai dengan 15 menit, dan 11 orang guru terlambat masuk kelas lebih dari 15 menit.
\end{abstract}

Tabel 1. Hasil Pengamatan siklus 1

\begin{tabular}{|c|c|c|}
\hline \multicolumn{3}{|c|}{ Waktu Keterlambatan/Jumlah/Persentase } \\
\hline $\begin{array}{c}\text { Kurang dari } \\
10 \text { menit }\end{array}$ & $\begin{array}{c}10 \text { menit s/d } 15 \\
\text { menit }\end{array}$ & $\begin{array}{c}\text { Lebih dari } 15 \\
\text { menit }\end{array}$ \\
\hline 4 & 6 & 8 \\
\hline $\mathbf{2 2 , 2 2 \%}$ & $\mathbf{3 3 , 3 3 \%}$ & $\mathbf{4 4 , 4 4 \%}$ \\
\hline
\end{tabular}

Dari data diatas dapat ditarik kesimpulan bahwa tingkat keterlambatan guru masuk kelas lebih dari 15 menit pada proses kegiatan belajar mengajar masih tinggi yaitu 8 orang atau 44,44\% Berdasarkan indicator yang telah ditetapkan bahwa keberhasilan tindakan ini adalah $75 \%$, atau bila $75 \%$ guru tidak terlambat lebih dari 10 menit. Pada siklus pertama ini guru yang tidak terlambat lebih dari 10 menit baru 22,22\%, jadi peneliti berkesimpulan harus diadakan penelitian atau tindakan lagi pada siklus berikutnya atau siklus kedua.

Berdasarkan hasil refleksi data siklus 1 maka peneliti melakukan pengamatan pada siklus 2. Dari hasil rekapitulasi tingkat keterlambatan guru di kelas pada proses pembelajaran diperoleh data, sebanyak 18 orang guru terlambat masuk kelas kurang dari 10 menit, 5 orang guru terlambat masuk kelas 10 menit sampai dengan 15 menit, dan tidak ada satu orangpun guru yang terlambat masuk kelas lebih dari 15 menit.

Tabel 1. Hasil Pengamatan siklus 2

\begin{tabular}{|c|c|c|}
\hline \multicolumn{3}{|c|}{ Waktu Keterlambatan/Jumlah/Persentase } \\
\hline $\begin{array}{c}\text { Kurang dari 10 } \\
\text { menit }\end{array}$ & $\begin{array}{c}10 \text { menit s/d } \\
15 \text { menit }\end{array}$ & $\begin{array}{c}\text { Lebih dari } \\
15 \text { menit }\end{array}$ \\
\hline 15 & 3 & 0 \\
\hline $\mathbf{8 3 , 3 3 \%}$ & $\mathbf{1 6 , 6 6 \%}$ & $\mathbf{0 , 0 0 \%}$ \\
\hline
\end{tabular}

Dari hasil observasi dan data yang diperoleh, peneliti mengambil kesimpulan bahwa tindakan yang dilaksanakan pada siklus kedua dinyatakan berhasil, karena terdapat $83,33 \%$ guru yang terlambat kurang dari 10 menit, atau melebihi target yang telah ditentukan sebesar $75 \%$.

\section{KESIMPULAN DAN SARAN Kesimpulan}

Berdasarkan analisis data, dari penelitian ini dapat ditarik kesimpulan bahwa penerapan Reward dan Punishment efektif untuk meningkatkan disiplin kehadiran guru di kelas pada kegiatan belajar mengajar. Data yang diperoleh menunjukan bahwa setelah diadakan penerapan tindakan berupa Reward dan Punishment, guru yang terlambat lebih dari 15 menit adalah 0 , dan guru yang terlambat kurang dari 10 menit sebanyak 
15 orang guru. Penerapan Reward dan Punishment dapat meningkat disiplin guru hadir di dalam kelas pada kegiatan belajar mengajar di SDI Wolowona 1.

\section{Saran}

Karena adanya pengaruh positif Penerapan Reward dan Punishment terhadap disiplin guru hadir di dalam kelas pada kegiatan belajar mengajar, maka melalui kesempatan ini penulis mengajukan beberapa saran :

1. Semua Kepada Kepala Sekolah disarakan melakukan Penerapan Reward dan Punishment untuk meningkatkan disiplin guru hadir di dalam kelas pada kegiatan belajar mengajar di sekolah.

2. Kepada semua guru dalam melaksanakan tugas untuk dapat meningkatkan disiplin dalam kehadiran dikelas sebagai bentuk pelayanan minimal kepada peserta didik disekolah.

\section{Daftar Pustaka}

Akhmad Sudrajat, (2010) Manfaat Prinsip dan Asas Pengembangan Budaya Sekolah. [On Line]. Tersedia : http://akhmadsudrajat.wordpress.co m/2010/03/04/manfaatprinsip-danasas-pengembangan-budaya-sekolah/ [06 Oktober 2010]

Amstrong. Michael, (1991). Manajemen Sumber Daya Manusia. Jakrta:Ghalia Indonesia

Anwar Prabu Mangkunegara. (1994). Psikologi Perusahaan. Bandung:PT. Trigenda Karya (2000). Manajemen Sumber Daya Manusia Perusahaan. Bandung : Penerbit Remaja Rosdakarya.

Arikunto, S. (2002). Prosedur Penelitian Suatu Pendekatan Praktek. Jakarta:Rineka Cipta.
Aunurrahman. (2009). Belajar dan Pembelajaran. Bandung:Alfabeta

Bambang Nugroho. (2006). Reward dan Punishment. Bulletin CiptaKarya Departemen Pekerjaan Umum Edisi No. 6/IV/Juni 2006

Departemen Pendidikan Nasional. (2003). Undang-undang Nomor 20 Tahun 2003 Tentang Sistem Pendidikan Nasional. Jakarta:Depdiknas

Hidayat, Sucherli. (1986). Peningkatan Produktivitas Organisasi dan Pegawai Negeri Sipil: Kasus Indonesia, Jakarta:Prisma

Megawangi, Ratna. (2007). Membangun SDM Indonesia Melalui Pendidikan Holistik Berbasis Karakter. Jakarta:Indonesian Heritage Foundation

Sanjaya, W. (2008). Kurikulum dan Pembelajaran. Teori dan Praktik Pengembangan Kurikulum Tingkat Satuan Pendidikan (KTSP). Jakarta:Kencana Prenada Media Group

Subagio. (2010) Kompetensi Guru dalam Meningkatkan Mutu Pembelajar an [On Line]. Tersedia : http://subagiosubagio.blogspot.com/2010/03/komp etensi-gurudalammeningkatkanmutu.html

Syamsul Hadi, (2009). Kepemimpinan Pembelajaran, Makalah Disampaikan pada Sosialisasi Akuntabilitas Kinerja Kepala Sekolah Dalam Inovasi Pembelajaran. Departemen Pendidikan Nasional, Direktorat Jenderal Peningkatan Mutu Pendidik dan Tenaga Kependidikan, Direktorat Tenaga Kependidikan 